\title{
The analysis of research methods and results on resistance of nickel-titanium endodontic instruments to torsion load: the systematic review
}

\author{
(c) D.S. Shirokova, Z.S. Khabadze, D.V. Voskresenskaya, F.R. Ismailov, Z.M Gasanova., N.N Fedotova \\ "Peoples' Friendship University of Russia" (RUDN University), Moscow, Russia
}

\begin{abstract}
:
Relevance. The objective of this study was to analyze current data concerning research methods and results on resistance of nickel-titanium endodontic instruments to torsion load in order to minimize complications of dental root canal treatment.

The use of the nickel -titanium endodontic instruments is a special importance to ensure high-quality dental root canal treatment; it prevents the further contamination of the canals with microorganisms. However, these instruments can form a fracture under torsional load which leads to further complications.

Aim. The analysis of research methods and results on resistance of nickel-titanium endodontic instruments to torsion load for minimization complications.

Materials and methods. A series of publications in the electronic databases such as Google Scholar, Pub Med was analyzed in the course of a systematic review of the literature. The articles dealing with nickel-titanium endodontic instruments and torsion load that directly influences the quality of dental root canal treatment were included in the paper. Results. 73 articles were viewed during the review. Having analyzed the literature for inclusion criteria, the total number of publications has become 51. There were 16 main methods which demonstrated the influence of torsion load on endodontic instruments. These methods were summarized in the Table 1.

Conclusions. As regards literature data, there are a various number of methods which converge to one conclusion: nickel-titanium instruments cannot fully resist torsion load. Fracture is caused approximately in $0,5-5 \%$ of cases.
\end{abstract}

Keywords: complications of dental root canal treatment, torsion load, nickel-titanium instruments.

Received: 14.09.2021; revised: 30.10.2021; accepted: 05.11.2021

Conflict of interests: The authors declare no conflict of interests.

For citation: D.S. Shirokova, Z.S. Khabadze, D.V. Voskresenskaya, F.R. Ismailov, Z.M Gasanova., N.N Fedotova. The analysis of research methods and results on resistance of nickel-titanium endodontic instruments to torsion load: the systematic review. Endodontics today. 2021; 19(4):320-325. DOI: 10.36377/1683-2981-2021-19-4-320-325.

\section{INTRODUCTION}

Endodontics is a branch of dentistry that includes the most important principles for the treatment of pulp pathologies and situations associated with its extirpation or amputation. In 1988, a new type of endodontic instrument made of nickel-titanium alloy appeared, which is more flexible and resistant to cyclic loads than the classic steel one. The use of these instruments made it possible to reduce the number of complications and increase the success rate of endodontic treatment.

But despite all the properties of nickel-titanium instruments (flexibility, cutting ability, resistance to cyclic and torsional loads, the severity of the screw-in effect), which the manufacturers claim, they can still lead to complications and errors in the root canals. And torsional loading is a key factor in these adverse situations.

Consequently, consideration of the methods and results of studies of the resistance of nickel-titanium endodontic instruments to torsion load is a rather complex topic that requires detailed elaboration.

\section{AIM}

The objective of the study was to analyse current data concerning research methods and results on resistance of nickel titanium endodontic instruments to torsion load in order to minimize complications of dental root canal treatment.

\section{MATERIALS AND METHODS}

Talking of materials and methods a series of publications in the electronic databases such as Google scholar and PubMed was analysed in the course of a systematic review of the literature. The articles dealing with nickel titanium Endodontic instruments and torsional load that directly influence the quality of dental root canal treatment were included in the paper.

Publications were included based on the following criteria:

1. Articles dated 2011 and later.

2. Study of the relevance of data on the effect of torsion load on nickel-titanium endodontic instruments.

T3. Consideration of methods and research results on the resistance of nickel-titanium instruments to torsion load. The subject of the study is a number of articles in electronic databases Google scholar and Pubmed. Consideration and analysis of articles were carried Out in stages.

First of all, the selection criterion was the choice of publications, the titles of which included at least one search value.

Secondly, works dated earlier than 2011 were excluded from the list.

At the last stage, the content of the full text variants of the selected articles was studied. The article selection process is shown in the Figure 1. 


\section{6зоры / Reviews 321}

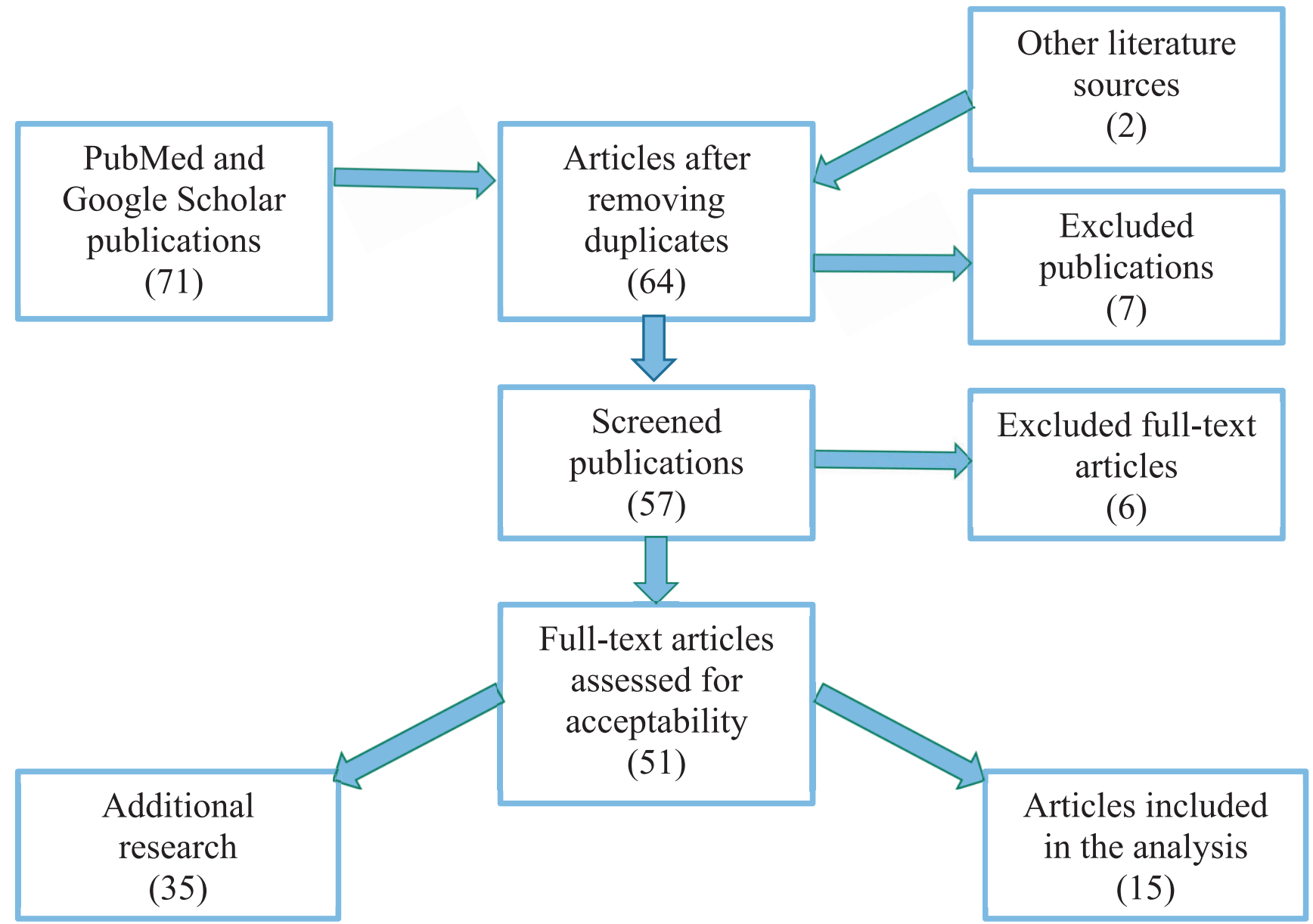

Fig. 1. Article selection process.

\section{RESULTS}

73 articles were considered, of which 6 were from the PubMed database, 65 from Google Scholar and 2 links from the list of references in the found publication. Having made a selection according to the exclusion criteria, the total number of works was 51 . On the basis of 15 articles, the methods and results of studies on the resistance of nickel-titanium instruments to torsion load were analyzed. Table 1 shows the characteristics of the studies presented.

\section{DISCUSSION}

According to the analyzed literature, there are a number of methods for studying the resistance of nickel-titanium instruments to torsion load.

Three studies used the so-called Endodontic Instrument Strength Tester device. The essence of this method was to determine the angle of twisting of the instrument relative to its longitudinal axis using a weight of 10 grams and a microscope. This situation is a prototype of the twisting of an endodontic instrument when its tip is jammed in the root canal during processing of the latter (artificial creation of a torsion load) [4, 11, 13].

Another method for studying the effect of torsional loading involved examining thin sections and fractures of $\mathrm{Ni}-\mathrm{Ti}$ instruments using a scanning electron microscope (SEM). This method made it possible to assess the deformations in tools and their design parameters [2, 9, $10,12,16]$.

Some studies have based on the effect of repeated use of endodontic instruments, as well as the way they are cleaned, as factors leading to instrument fractures in the root canals. For this, the instruments were differentiated depending on their use or autoclaving $[11,13]$.

The next method was to create two types of channel models. The models were curved glass tubes, the bending angle of which was selected so that the tool deviated from the original direction by an angle of 45 degrees, and the bending radius of the tool was within $5-6 \mathrm{~mm}$. This method made it possible to neglect the torsion load and drew attention to the cyclic one, thereby simplifying the task. But at the same time, this method proved "by contradiction" the significance of the torsion load in the event of fracture, because if we complicate the task, taking into account this type of load, then the path taken in this study will seem impossible. [3, 27, 28]

Brazilian dentists have also made a link between the shape of the canal and the frequency of use of endodontic instruments. 3 groups were defined according to the criteria indicated in Table 1, and they were tested for torsion load and torque in an artificially created steel root canal. The results showed that the maximum torque after fracture tends to increase in proportion to the tool diameter (size and taper). The maximum angular deflection at failure also tends to increase with increasing tool diameter. [16, 36-39]

The method of other studies was the use of a dental phantom model "Model for determining the cyclic strength of mechanical endodontic instruments in the preparation of root canals of teeth." It has a metal in which 3 channels are made curved at $45^{\circ}, 60^{\circ}$ and $90^{\circ}$ at a distance of 14 $\mathrm{mm}, 13 \mathrm{~mm}$ and $12 \mathrm{~mm}$ respectively from the entrance to the channels. The model allows to determine the cyclic strength of mechanical endodontic instruments and allows 
Table 1. Characteristics of the studies included in the review.

\begin{tabular}{|c|c|c|c|}
\hline Author, year & Research objects & Research method & Result \\
\hline E.A. Rzhanov, 2011 [1] & $\begin{array}{c}\text { Ultra-flexible steel rotatable } \\
\text { endodontic instrument }\end{array}$ & $\begin{array}{c}\text { Theoretical study of the material on the effect of torsion load } \\
\text { on Ni-Ti endodontic instruments, taking into account all } \\
\text { factors causing fractures and creating an ultra-flexible steel } \\
\text { specimen }\end{array}$ & $\begin{array}{l}\text { The torsion resistance of this tool is high, } \\
\text { since all the disadvantages of conventional } \\
\text { Ni-Ti tools have been studied and taken into } \\
\text { account. }\end{array}$ \\
\hline T.A. Belyaeva, 2013 [2] & $\begin{array}{l}\text { Ni-Ti instruments: 1) } \\
\text { ProFile, 2) FlexMaster, 3) } \\
\text { ProTaper, 4) BioRace , 5) } \\
\quad \text { Mtwo }\end{array}$ & $\begin{array}{l}\text { 1) Research was carried out on electronic scanning } \\
\text { microscope (SEM) at magnifications from x } 25 \text { to } \times 120 \text {. } \\
\text { Measurement: 1) cutting angle; 2) cutting steps; } 3 \text { ) inner } \\
\text { and outer diameters; } 4 \text { ) apex angle; } 5 \text { ) corners of the cutting } \\
\text { blade 2) The clinical part of the study included } 74 \text { patients } \\
\text { from } 24 \text { to } 62 \text { years old, of which women - } 62 \% \text {, men - } 38 \% \text {. } \\
\text { During the study, } 240 \text { root canals of } 137 \text { teeth were prepared. } \\
\text { All the canals of the teeth were divided into Vl groups of } 40 \\
\text { canals }\end{array}$ & $\begin{array}{l}\text { Torsion resistance is increased with } \\
\text { increasing size and taper of instruments }\end{array}$ \\
\hline $\begin{array}{l}\text { E.A. Rzhanov, } \\
\text { D.A. Kopyev, } 2011 \text { [3] }\end{array}$ & $\begin{array}{l}\text { FlexMaster 25/.04 } 100 \\
\text { instruments }\end{array}$ & $\begin{array}{l}\text { To conduct an experimental models were made - glass tubes } \\
\text { of } 2 \text { types, creating situations with difficult working conditions } \\
\text { of the instruments, due to the anatomy of the root channels }\end{array}$ & $\begin{array}{l}\text { Too high uncertainty of the formation } \\
\text { of a fracture reduces the computational } \\
\text { procedure to nothing. When complicating the } \\
\text { experiment by taking into account the torsion } \\
\text { load, it makes predicting the time to tool } \\
\text { breakage is impossible }\end{array}$ \\
\hline $\begin{array}{c}\text { T.N. Manak, } \\
\text { V.G.Devyatnikova, 2012 [4] }\end{array}$ & $\begin{array}{c}\text { Endodontic tools of the } \\
\text { ProTaper system (10 new } \\
\text { files, } 10 \text { after one time use, } \\
10 \text { after five times of use) }\end{array}$ & $\begin{array}{l}\text { An original device for studying the physical and mechanical } \\
\text { properties of endodontic instruments has been developed }\end{array}$ & $\begin{array}{l}\text { Even a single use of endodontic instruments } \\
\text { can lead to breakage during treatment. }\end{array}$ \\
\hline $\begin{array}{l}\text { A.A.Adamchik, F. } \\
\text { M. Laipanova, } 2016 \text { [5] }\end{array}$ & $\begin{array}{l}\text { 1) «One Shape»(«Micro- } \\
\text { Mega»,France) } 2 \text { ) «F 360» } \\
\text { («Komet/Gebr.Brasseler, } \\
\text { Lemgo», Germany) }\end{array}$ & $\begin{array}{l}\text { Using the dental phantom model "Model for determining the } \\
\text { cyclic strength of mechanical endodontic instruments for the } \\
\text { preparation of root canals of teeth " }\end{array}$ & $\begin{array}{l}\text { These nickel-titanium instruments, subject } \\
\text { to the recommendations for use, depending } \\
\text { on the bending of the root canal after the } \\
\text { experiment, made it possible to prevent the } \\
\text { risks of instrument breakage in the root canal } \\
\text { during mechanical processing of the root } \\
\text { canal. }\end{array}$ \\
\hline $\begin{array}{l}\text { T.O. Paderina, } \\
\text { Yu.A. Dombrovskaya, } 2020 \\
{[6]}\end{array}$ & $\begin{array}{l}\text { Proteapers: 1)Mailliefer } \\
\text { Universal (Dentsplay) 2) } \\
\text { Ultrataper (Eurofile) 3) } \\
\text { Superfile (Eurofile) }\end{array}$ & $\begin{array}{l}\text { Energy dispersive microanalysis tools using a tabletop } \\
\text { scanning electron microscope TM3000 }\end{array}$ & $\begin{array}{l}\text { Energy dispersive microanalysis of the } \\
\text { fracture surfaces of rotary tools revealed } \\
\text { the chemical heterogeneity of the alloy, } \\
\text { which can affect the brittleness of the tools } \\
\text { and change the resistance to various loads } \\
\text { depending on the content of one or another } \\
\text { element in the alloy. }\end{array}$ \\
\hline $\begin{array}{l}\text { A.A. Adamchik, } \\
\text { A.V. Arutyunov, V.V. Tairov, } \\
\text { Val V. Tairov, } 2016[7]\end{array}$ & $\begin{array}{l}\text { 1)"One Shape" № 025, } \\
\text { L25 6\% (Micro-Mega) } \\
\text { 2)"F 360" (Komet/Gebr. } \\
\text { Brasseler, Lemgo) }\end{array}$ & $\begin{array}{l}\text { 1) Using a dental phantom - a stainless steel root canal with } \\
\text { a curvature angle of } 45^{\circ} \text { and a total length of } 30 \mathrm{~mm} \text {, tightly } \\
\text { fixed to a wooden plate 2) Clinical study involving } 20 \text { patients } \\
\text { aged } 22 \text { to } 60 \text { with a diagnosis of K04.0 }\end{array}$ & $\begin{array}{l}\text { Disposable NiTi Rotary Machine Tools } \\
\text { System "F 360" \# } 025 \text { L25 4\% (Komet / } \\
\text { Gebr. Brasseler, Lemgo, Germany) showed } \\
\text { significant superior fracture versus "One } \\
\text { Shape" System \# 025, L25 6\% (Micro-Mega) }\end{array}$ \\
\hline $\begin{array}{l}\text { L.Yu. Orekhova, V.Yu. } \\
\text { Vashneva, T.V. Porkhun, } \\
\text { Yu.A. Zaitseva, } 2020 \text { [8] }\end{array}$ & $\begin{array}{l}\text { Alloy tools M-Wire: } \\
\text { 1)Reciproc Blue } \\
\text { (VDW,Germany) 2) Mtwo- } \\
\text { file (VDW,Germany) 3)Soco } \\
\text { SC Pro (Soco,China) }\end{array}$ & $\begin{array}{l}\text { 1) In the study, } 30 \text { extracted teeth were used, } 47 \text { root canals } \\
\text { were processed. All studies were carried out on extracted } \\
\text { teeth with the curvature of the root canal is more than } 25 \\
\text { degrees. Allocated } 3 \text { groups ( } 10 \text { teeth in each group) } 2 \text { ) Thin } \\
\text { sections were made and the results were assessed on the } \\
\text { electronic scanning microscope }\end{array}$ & $\begin{array}{l}\text { Nickel-titanium instruments made of M-Wire } \\
\text { alloy (Reciproc Blue and Soco SC Pro) allow } \\
\text { mechanical processing of curved root canals } \\
\text { with preservation of their anatomy in a short } \\
\text { period of time. This grade increases the } \\
\text { flexibility of the tool, while maintaining cutting } \\
\text { efficiency, resistance to cyclic fatigue and } \\
\text { torsional stress }\end{array}$ \\
\hline $\begin{array}{c}\text { Vivan RR, Alcalde MP, } \\
\text { Candeiro G, Gavini G, } \\
\text { Caldeira CL, Duarte MAH, } \\
2019 \\
{[9]}\end{array}$ & $\begin{array}{c}60 \text { instruments (by 20) } \\
\text { systems: 1)ProDesign R 2) } \\
\text { Reciproc R25 3)Unicode } \\
\text { L25 }\end{array}$ & $\begin{array}{l}\text { 1) analysis of the mass and amount of metal (Skyscan } \\
1174 \text { v2; Bruker-micro-CT, Kontich, Belgium; CTAn v.1. } 12 \\
\text { (Bruker-micro-CT), three-dimensional analysis of the volume } \\
\text { of the metal mass (NRecon v. 1.6.3, Bruker -micro-CT) 2) } \\
\text { Torsion test 3) Using EMS }\end{array}$ & $\begin{array}{l}\text { The R-Pilot file is stronger than the G - it } \\
\text { turned out to be less resistant to fracture. } \\
\text { The R file has a larger cross-sectional area } \\
\text { and metal mass volume than G. The SEM } \\
\text { assessment of the fracture surface revealed } \\
\text { similar and typical fracture patterns for both } \\
\text { tools. }\end{array}$ \\
\hline $\begin{array}{l}\text { Soram Oh, Kee-Yeon Kum, } \\
\text { Kwon Cho, Soo-Hyuk Lee, } \\
\text { Seung-Hyun You, Jonggun } \\
\text { Go, Bong-Ki Jeon, } \\
\text { Sang-Woo Kim, Tae-Hwan } \\
\text { Kim, Ji-Hyun Jang, Hiran } \\
\text { Perinpanayagam, Jin-Woo } \\
\text { Kim et al., 2019 [10] }\end{array}$ & $\begin{array}{c}\text { Ni-Ti endodontic } \\
\text { instruments: 1) PTN } \\
\text { (Dentsply Maillefer) 2) V2H } \\
\text { (Colténe/Whaledent, Inc) 3) } \\
\text { NRT (Mani) 4) OS (Micro } \\
\text { Mega) }\end{array}$ & $\begin{array}{c}\text { 1) Each file was installed in a composite polymer block with } \\
\text { a } 5 \mathrm{~mm} \text { working end. The files were subjected to torsion load } \\
\text { ( } 300 \mathrm{rpm} \text { ) with an automatic stop until they were destroyed. } \\
\text { The number of approaches that resulted in the destruction } \\
\text { of the instruments was recorded. 2) All crack surfaces were } \\
\text { examined using SEM }\end{array}$ & $\begin{array}{l}\text { V2H withstands torsional loads to a large } \\
\text { extent, OS minimally }\end{array}$ \\
\hline
\end{tabular}




\section{6зоры / Reviews}

\begin{tabular}{|c|c|c|c|}
\hline Author, year & Research objects & Research method & Result \\
\hline $\begin{array}{c}\text { Devyatnikova V.G. Manak } \\
\text { T.N., } 2020 \\
{[11]}\end{array}$ & $\begin{array}{l}216 \text { instruments of } \\
\text { nickel-titanium endodontic } \\
\text { systems: 1) } 72 \text { tools of } \\
\text { the Protaper Universal } \\
\text { system (25/07-regular } \\
\text { Ni-Ti) Dentsply Maillefer 2) } \\
72 \text { tools system Endostar } \\
\text { E3 Basic Rotary System } \\
\text { (25/06-regular NiTi) } \\
\text { POLDENT 3) } 72 \text { tools of } \\
\text { the Protaper Next system } \\
\text { (25/06 - M-Wire alloy) } \\
\text { Dentsply Maillefer }\end{array}$ & $\begin{array}{l}\text { 1) Division of systems into groups, depending on the } \\
\text { bending angle of the artificial root canal } 45(n=36) \text { or } 60 \\
\text { ( } n=36 \text { ) degrees, respectively. Each group was divided into } \\
\text { three subgroups depending on the number of autoclaving } \\
\text { cycles: } 1 \mathrm{a}(\mathrm{n}=12) \text { and } 2 \mathrm{a}(\mathrm{n}=12) \text { instruments without } \\
\text { autoclaving, } 1 \mathrm{~b}(\mathrm{n}=12) \text { and } 2 \mathrm{~b}(\mathrm{n}=12) \text { instruments after } \\
\text { one autoclaving cycle, and } 1 \mathrm{c}(\mathrm{n}=12) \text { and } 2 \mathrm{c}(\mathrm{n}=12) \\
\text { instruments after six autoclaving cycles. } 2 \text { ) The elemental } \\
\text { composition of samples of endodontic files was studied } \\
\text { using an X-ray spectral analyzer from Oxford Instruments } \\
\text { Analytical (Great Britain). 3) Test with the device "Endodontic } \\
\text { instrument strength tester" }\end{array}$ & $\begin{array}{l}\text { Failure of endodontic instruments resulted } \\
\text { from cyclic alloy fatigue metal. In real } \\
\text { conditions of passage channel, the file } \\
\text { experiences both torsion and cyclic loads at } \\
\text { the same time }\end{array}$ \\
\hline $\begin{array}{l}\text { Belyaeva T.S., Rzhanov } \\
\text { E.A., } 2012 \text { [12] }\end{array}$ & $\begin{array}{l}30 \text { ProFile instruments: } \\
\text { Dentsply Maillefer, } \\
\text { Ballaigues, Switzerland in } \\
\text { the following sizes: } 20.04 \text {, } \\
25.04,30.04,20.06,25 \\
.06 \text { and } 30.06 \text { (five tools of } \\
\text { each size) }\end{array}$ & $\begin{array}{l}\text { 1) Obtaining a microphotogram of the working part of } \\
\text { the instruments at magnifications of } \times 25, \times 100 \text { and } \\
\times 120 \text { using a scanning electron microscope (SAM) } 2 \text { ) } \\
\text { Create cross-sections of tools } 3 \text { ) Measurement of design } \\
\text { parameters of tools: } 1 \text {.apex angle } 2 \text {.Slicing angle } 3 . \text { slicing } \\
\text { steps } 4 \text {.cutting depth } 5 \text {.inner and outer diameters } 6 . t \text { the front } \\
\text { corner of the cutting blade } 7 \text {. Rear angle of the cutting blade } \\
\text { 8. angle of sharpness of the cutting blade. }\end{array}$ & $\begin{array}{l}\text { ProFile instruments have a low Dw / Dn value } \\
\text { (about } 0.6 \text { ), which indicates their flexibility } \\
\text { and resistance to cyclic loads. At the same } \\
\text { time, this indicator indicates the relatively low } \\
\text { resistance of these tools to torsion loads. }\end{array}$ \\
\hline $\begin{array}{c}\text { Manak T.N., Devyatnikova } \\
\text { V.G., E.V. Radivilina, } 2019 \\
{[13]}\end{array}$ & $\begin{array}{c}\text { ProTaper Universal (files F1 } \\
\# 20 \text {, taper } 7 \% \text { ) }\end{array}$ & $\begin{array}{l}\text { 1) Dividing samples into } 3 \text { groups: No. } 1 \text { - "new } \\
\text { instrument". No. } 2 \text { - "tool after one use." No. } 3 \text { - "tool after } \\
\text { five uses." 2) Creation of a device for testing the strength } \\
\text { of endodontic instruments, which makes it possible to } \\
\text { determine the angle of twisting of an endodontic instrument } \\
\text { under conditions approximate to the twisting of the file when } \\
\text { its tip is jammed in the root canal during processing of the } \\
\text { latter. }\end{array}$ & $\begin{array}{l}\text { 1) Dividing samples into } 3 \text { groups: No. } \\
1 \text { - "new instrument". No. } 2 \text { - "tool after } \\
\text { one use." No. } 3 \text { - "tool after five uses." 2) } \\
\text { Creation of a device for testing the strength } \\
\text { of endodontic instruments, which makes it } \\
\text { possible to determine the angle of twisting of } \\
\text { an endodontic instrument under conditions } \\
\text { approximate to the twisting of the file when } \\
\text { its tip is jammed in the root canal during } \\
\text { processing of the latter. }\end{array}$ \\
\hline $\begin{array}{c}\text { Viana AC, Chaves Craveiro } \\
\text { de Melo M, Guiomar de } \\
\text { Azevedo Bahia M, Lopes } \\
\text { Buono VT, 2010 } \\
\text { [14] }\end{array}$ & 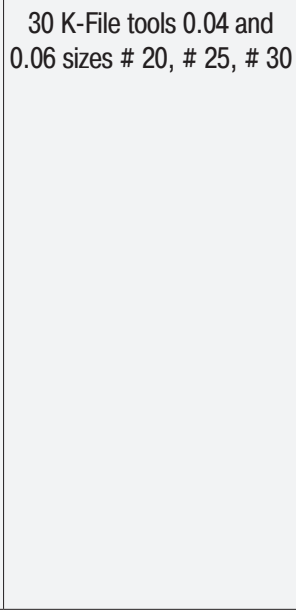 & $\begin{array}{l}\text { 1) in total } 180 \text { files were randomly divided into } 3 \text { groups of } \\
10 \text { sets each (No. } 20 / 0.04, \text { No. } 25 / 0.04, \text { No. } 30 / 0.04 \text {, } \\
\text { No. } 20 / 0.06 \text {, No. } 25 / 0.06 \text { and No. } 30 / 0.06 \text { ). Division of } \\
\text { instruments into } 3 \text { groups: Control group - new files tested } \\
\text { for the effect of torsion load. (Setting the average value of } \\
\text { the torsion load before failure and the maximum angular } \\
\text { deviation of each file); Experimental Group } 1 \text { - New files, } \\
\text { tested on a fatigue tester up to half of their predetermined } \\
\text { service life, and then torsionally tested to fracture; d } \\
\text { Experimental Group } 2 \text { - New files tested on a fatigue tester } \\
\text { up to three quarters of their previously stated service life and } \\
\text { then torsion tested to fracture; } 2 \text { ) Device allowed files freely } \\
\text { rotate inside an artificial curved canal made of become; } 3 \text { ) } \\
\text { Continuous registration of torque and angular deviation and } \\
\text { measurement of maximum torque and angular deflection } \\
\text { was provided by a specially designed computer program; 4) } \\
\text { SEM control }\end{array}$ & $\begin{array}{l}\text { Maximum torque after fracture tends to } \\
\text { increase in proportion to the tool diameter } \\
\text { (size and taper). Maximum angular failure } \\
\text { deflection also tends to increase with } \\
\text { increasing tool diameter }\end{array}$ \\
\hline Kopyev D.A., 2012 [15] & $\begin{array}{c}100 \text { broken nickel- } \\
\text { titanium instruments and } \\
39 \text { recovered fragments } \\
\text { (Profile (Densply), } \\
\text { Race (FKG), ProTaper } \\
\text { (Dentsply), FlexMasteo) } \\
\text { (VDW) and M two (VDW)). }\end{array}$ & $\begin{array}{l}\text { Clinical researches: · retrospective analysis of } 113 \text { X-ray } \\
\text { images, distribution of patients into clinical groups (main - } \\
86 \text { patients, control - } 77 \text { patients) depending on the } \\
\text { algorithm application · primary endodontic treatment of } 253 \\
\text { teeth Laboratory methods: · analysis of broken nickel- } \\
\text { titanium instruments and recovered fragments. · Electron } \\
\text { microscopic examination of the end surface of broken } \\
\text { nickel-titanium instruments of different systems · Simulation } \\
\text { of cyclic load on endodontic instrument "Flex Master" (VDW) } \\
\text { with } 9 \text { tip diameter } 0.25 \text { mm and taper .04. in the experiment. } \\
\text { • Experimental investigation of the breakage probability of } \\
100 \text { "Flex Master" (VDW) nickel-titanium instruments with } \\
\text { a tip diameter of .25 / .04. depending on the duration of its } \\
\text { operation in a curved channel. }\end{array}$ & $\begin{array}{l}\text { Typical } 04 \text { size } 25 \text { taper nickel-titanium tools } \\
\text { have limited operating time and should be } \\
\text { excluded from the list used after about } 1 \\
\text { minute of operation in a curved canal in full } \\
\text { rotation mode at a speed of } 300 \text { rpm }\end{array}$ \\
\hline
\end{tabular}

to increase the force of resistance to torsion load. It is recommended for the selection of endodontic mechanical instruments of a certain size and taper depending on the bending angle of the root canal of the tooth, thereby preventing possible risks of instrument breakage $[5,7]$.
Such a method as carrying out energy dispersive microanalysis made it possible to assess the nature of the formation of fractures from the chemical currents of view [6]. 


\section{4| 06зоры / Reviews}

Table 2. Root canal anatomy and torsion load.

\begin{tabular}{|l|c|}
\hline Canal type & Effect of torsion load \\
\hline Wide canals & The tool does not experience torsional overload \\
\hline Narrow straight canals & The tool is subjected to significant torsional loads \\
\hline Wide curved canals & The tool does not experience a high torsion load \\
\hline Narrow and curved canals & $\begin{array}{c}\text { The tool is subjected to significant torsional and } \\
\text { cyclic loads }\end{array}$ \\
\hline
\end{tabular}

Studies by foreign authors have also made a great contribution to the study of torsion load. Analysis of the mass and amount of metal made it possible to determine the qualitative composition of tools and their strength under the influence of loading. A three-dimensional analysis of the volume of the metal mass was also carried out, which made it possible to fully recreate the characteristics of the tool. The torsion test clearly showed the value of the load in the development of the fracture of the endodontic instrument [9, 29-31].

Another study looked at the effect of direct torsional loading (300 rpm) on auto-stop tools installed in a polymer block until they were destructible. The number of approaches leading to the destruction of the instruments was recorded, and all the defects that occurred were investigated using SEM [10].

Another method of investigating the effect of torsion load was the study of the qualitative characteristics of instruments. The torsional stability of a rotary nickeltitanium tool is also determined by the value of its inner diameter: the smaller the inner diameter of the tool, the less its resistance to breakage during torsional overload in this area [2, 22-26]. The ratio of the inner and outer diameters of the tool indicated a relatively low resistance of the investigated $\mathrm{Ni}$-Ti tools to torsion loads [12, 46-51].

But the resistance to torsional loads increases with the size and taper of the tools. When comparing tools of different systems of the same size and taper, it can be seen that stability increases in the following order: BioRaCe $\approx$ Mtwo < ProFile $\leqslant$ ProTaper < FlexMaster [2, 24, 26].

The method of theoretical study of the effect of torsion load revealed that the conical shape of the cutting part of endodontic instruments is potentially dangerous due to the fact that it contributes to the uneven distribution of the angle of twisting along the axis of the instrument. As a result, there is a concentration of torsion load in the area of the apex of the instrument, which at the moment of overloading can lead to shear deformation and subsequent

\section{REFERENCES:}

1. Rzhanov E. A. Principles of creating endodontic instruments due to the anatomy of the dental root canal system. Ultra-flexible rotating endodontic instrument. Endodontia Today. 2011;9(1):25-27. (In Russ.)

2. Belyaeva T.S. Comprehensive clinical and laboratory comparative analysis of systems of rotary endodontic instruments made of nickeltitanium alloy. Dissertation for the degree of candidate of medical sciences. 616.314-089.23:615.47. (In Russ.)

3. Rzhanov, E. A., Kopiev D.A. Method for assessing the probability of nickel-titanium instrument breakage depending on the duration of its operation in a curved channel. Endodontia Today. 2011;2:66-72.

4. Manak T.N. Evaluation of the physical and mechanical properties of $\mathrm{Ni}-\mathrm{Ti}$ endodontic instruments. Stomatolog. 2012;3(6):45-48.

5. Adamchik A.A., Laipanova F.M. Clinical and experimental study of rotating nickel-titanium endodontic instruments. Kuban Scientific Medical Bulletin. 2016;(4):7-11. (In Russ.)

6. Paderina T.O. Analysis of the structural features of $\mathrm{Ni}-\mathrm{Ti}$ instruments after their fracture. Proceedings of the 93rd All-Russian Scientific and Practical Student Conference with International Participation. 29 -30 April 2020

7. Adamchik A.A. , Arutyunov A.V. , Tairov V.V. Comparison of Cyclic Fatigue of Endodontic Machine Nickel-Titanium Instruments (Experimental Clinical Study). Stomatologia dla vseh. 2016;2: 48-53. breakage of the instrument in the apical third of the canal [1, 18-21, 46-51].

In a number of studies, clinical bases with patients were used to clarify the results of the experiment, and extracted teeth were also used to test the torsion load on natural preparations [2, 7, 8, 32-35].

The differentiation of the results for each individual study is presented in Table 1. But all authors agree on one thing: Ni-Ti tools break approximately in the range from $0.5 \%$ to $5 \%$ [14]. Even in the case of using disposable representatives, the likelihood of fracture formation, although insignificant, is available.

In addition, it was found that the stability of $\mathrm{Ni}-\mathrm{Ti}$ instruments also depends on the anatomy of the canal. The results of the relationship between the anatomy of the root canals and the effect of torsion load on the instrument are summarized in Table 2.

Analysis of the modeling of cyclic and torsional loads on endodontic instruments revealed the following regularities of the influence of the canal and instrument geomephy on the level of bending deformation of the file. The magnitude of the maximum deformation increases with:

1. increasing the depth of immersion in the channel;

2. a decrease in the radius of the channel curves;

3. an increase in the angle of curvature of the channel;

4. an increase in the taper of the tool [17, 40-45].

\section{CONCLUSIONS}

The properties of the $\mathrm{Ni}-\mathrm{Ti}$ alloy provide relatively high flexibility of the instruments, and the high taper - a significant rate of tissue removal. Despite the obvious advantages, nickel-titanium tools are not devoid of some disadvantages due to both the material properties and, to a greater extent, the design features. In practical terms, it is essential that in the process of work, they relatively often break, and these fractures are poorly predictable, and, as a rule, occur unexpectedly for the endodontist. Fracture of an instrument in the canal is one of the most severe iatrogenic complications of endodontic treatment, since a block appears in the canal, which prevents further canal processing, its adequate cleaning and filling. The statistics of torsional breakages of various types of states that the fracture of instruments occurs in the area close to the apex [15]. In addition, autoclaving, use of instruments for an extended period of time, inattentive canal preparation all these factors can lead to the vulnerability of $\mathrm{Ni}$-Ti endodontic instruments to torsion loading.

8. Orekhova L. Yu., Vashneva V. Yu., Porkhun T. V., Zaitseva Yu. A. Comparative efficiency of mechanical treatment of root canals with modern ni-ti instruments. Endodontia Today. 2020; 18(2):10-15.

9. Vivan RR, Alcalde MP, Candeiro G, Gavini G, Caldeira CL, Duarte $\mathrm{MAH}$. Torsional fatigue strength of reciprocating and rotary pathfinding instruments manufactured from different NiTi alloys. Braz Oral Res. 2019;33:97.

10. Oh S., Kum K.Y., Cho K., Lee S., You S., Go J. et al. Torsional and Bending Properties of V Taper $2 \mathrm{H}$, ProTaper NEXT, NRT, and One Sha. Biomed Res Int. 2019.

11. Devyatnikova, V.G., Manak T.N. Experimental study of factors influencing the breakdown of a cyclic nature in rotary endodontic instruments. Endodontia Today. 2020;18(1):4-14.

12. Belyaeva, T. S., Rzhanov E. A. Research of the design parameters of the system of rotary endodontic instruments ProFile. Endodontia Today. 2012;10(4):9-17.

13. Manak, T. N. Experimental study of the physical and mechanical properties of nickel-titanium rotary endodontic instruments. International reviews: clinical practice and health. 2019;1(33):85-96

14. Viana AC, Chaves Craveiro de Melo M, Guiomar de Azevedo Bahia M, Lopes Buono VT. Relationship between flexibility and physical, chemical, and geometric characteristics of rotary nickel- 
titanium instruments. Oral Surgery, Oral Medicine, Oral Pathology, Oral Radiology, and Endodontology. 2010;110(4):527-533.

15. Kopyev D.A. Treatment of teeth containing fragments. Dissertation for the degree of candidate of medical. 2012;134. ( In Russ.).

16. Cheung G.S. Instrument fracture: mechanisms, removal of fragments, and clinical outcomes. Endodontic Topics. 2007;16:1-26.

17. Bahia MG, Melo MC, Buono VT. Influence of simulated clinical use on the torsional behavior of nickel-titanium rotary endodontic instruments. Oral Surgery, Oral Medicine, Oral Pathology, Oral Radiology, and Endodontology. 2006;101(5):675-680.

18. Rzhanov E.A. A.V.Bolyachin Nickel-titanium alloy instruments used in endodontics. Clinical dentistry. 2004;2: 26-32.

19. Kim S., Endodontic Microsurgery, congress IFEA 2010, Greece.

20. Landau, L. D., Lifshits, E. M., Kosevich, A. M., \& Pitaevskiī, L. P. Theory of elasticity. Oxfordshire: Pergamon Press. 1986.

21. Peters OA, Peters Cl, Schönenberger K, Barbakow F. ProTaper rotary root canal preparation: effects of canal anatomy on final shape analysed by micro CT. International Endodontic Journal. 2003;36(2):86 92.

22. Alapati SB, Brantley WA, Svec TA, Powers JM, Nusstein JM, Daehn GS. SEM observations of nickel-titanium rotary endodontic instruments that fractured during clinical Use. J Endod. 2005;31(1):40 43.

23. Al-Fouzan KS. Incidence of rotary ProFile instrument fracture and the potential for bypassing in vivo. International Endodontic Journal. 2003;36(12):864-867.

24. Al-Hadlaq SM, Aljarbou FA, AIThumairy RI. Evaluation of cyclic flexural fatigue of M-wire nickel-titanium rotary instruments. J Endod. 2010;36(2):305-307

25. Anderson ME, Price JW, Parashos P. Fracture resistance of electropolished rotary nickel-titanium endodontic instruments. J Endod. 2007;33(10):1212-1216.

26. Andreasen G.F., Hilleman T.B. An evaluation of 55 cobalt Nitino wire for use in orthodontics. Journal of American Dental Association. 1971;6(82): 1373-1375.

27. Jeremy M. Young, Krystyn J. Van Fliet. Predicting in vivo failure of pseudoelastic NiTi devices under low cycle, high amplitude fatigue. Willey Periodicals Inc. J. Biomed Mater Res. Part B: Appl Biomater 2005:17-26.

28. Schafer E., Diez C., Hoppe W., Tepel J. Roentgenographic investigation of frequency and degree of canal curvatures in human permanent teeth. J. Endod. 2002;28 (3):211-216.

29. Emelyanov, D.V. Review of the causes of breakage of nickeltitanium endodontic instruments in the root canal. Conference dedicated to the 25th anniversary of ZAO SEZ VladMiVa, Belgorod Publishing House "Belgorod". 2017;173-175.

30. Baek SH, Lee CJ, Versluis A, Kim BM, LeeW, Kim HC. Comparison of torsional stiffness of nickel-titanium rotary files with different geometric characteristics. J Endod. 2011;37 (9):1283.

31. Sousa-Neto MD, Silva-Sousa YC, Maz zi-Chaves JF, et al. Roo canal preparation using micro-computed tomography analysis: a literature review. Braz Oral Res. 2018;32 (1):66

32. Gazhva S.I., Pillipenko K.I., Gurenkova N.A., Zyzov I.M. Errors and complications of endodontic treatment of different groups of teeth. Ural Medical Journal. 2011;5 (83):17-21.

33. Rumyantsev V.A., Nekrasov A.V., Moiseev D.A., Zadorozhny D.V., Pankin P.I. Biofilm in endodontics, part II. methods of biofilm contro

\section{AUTHOR INFORMATION:}

D.S. Shirokova - student, ORCID ID: 0000-0002-1309-8516

Z.S. Khabadze - Candidate of Medical Sciences, Associate Professor, Department of Therapeutic Dentistry, ORCID ID: 0000-0002-7257-5503.

D.V. Voskresenskaya - student.

F.R. Ismailov - postgraduate student, Department of Therapeutic Dentistry

Z.M Gasanova - Candidate of Medical Sciences, senior lecture, Department of Therapeutic Dentistry.

N.N Fedotova - Candidate of Medical Sciences, senior lecture, Department of Therapeutic Dentistry.

"Peoples' Friendship University of Russia" (RUDN University), Moscow, Russia. in endodontic dental treatment (literature review). Endodontia Today. 2018;2:38-42.

34. Rabinovich I.M., Abakarova D.S., Snegirev M.V. Root canal (he key to endodontic success: an overview. Dentistry. 2011 $80-83$ - vs. multiplevisit endodontic therapy of nonvital teeth: a taanalysis. J.Con-temp. Dent. Pract. 2017;18:330-336.

36. Thompson S.A. An overview of nickel-titanium alloys used in . 2000:33:297-310.

doi: 10.1046/j.1365-2591.2000.00339

37. Weine F.S. Kelly R.F. Lio P.J. The effect of preparation procedures on original canal shape and on apical foramen shape. J Endod. 1975;1: 255-262.

38. Blum J.Y. Machtou P. Micallef J.P. Location of contact areas on rotary ProFile instruments in relationship to the forces developed during mechanical preparation on extracted teeth. International Endodontic ournal 1999:32:108-114.

39. Hilt B.R. Cunninghan C.J. Shen C. Richards N. Torsinal properties of stainless-steel and nickel-titanium files after multiple autoclave Endod 2000:26:76-80.

40. Bir R. Errors of endodontic treatment and their elimination. 2400-265

41. Bir R. Endodontology. Medpress. 2006: 363

2. Bokaya V.G. Dspophoresis of calcium copper hydroxide in the of scientific papers of the 4th Congress of the Dental Association of Russia. 2002: 3739.

43. Bolyachin A.B. Design features of active Ni-Ti instruments. $003 ; 1(3): 53-56$

44. Borovskiy E.V. Yes or no to the resorcinol-formalin method . Clinical Dentistry. 1997:3:16-18.

. Hartwell G. Distortion. Breakage of Liberator, EndoSequence, and ProFile systems in severely curved roots of molars. Journal of Endodontics. 2010;36 (4):729-731.

47. Oh S.R., Chang S.W., Lee Y., Gu Y., Son W.J., Lee W., Baek S.H., Bae K.S., Choi G.W., Lim S.M., Kum K.Y. A comparison of nickeltitanium rotary instruments manufactured using different methods and cross-sectional areas: ability to resist cyclic fatigue. Oral Surgery, Oral Medicine, Oral Pathology, Oral Radiology, and Endodontology. 10;109 (4):622-628.

48. Plotino G., Grande N.M., Melo M.C., Bahia M.G., Testarelli L., P. Cyclic fatigue of NiTi rotary instruments in a simulated (nternational Endodontic Journal. 2010;43 :226-230

49. Vahid A., Roohi N., Zayeri F. A comparative study of four rotary . change of working length. Australian Endodontic Journal. 2009;35 (2):93-97.

50. Chow D.Y., Stover S.E., Bahcall J.K., Jaunberzins A., Toth Vile Systems. Journal of Endodontics. 2005;3(3):180-182.

51. Sonntag D. Schneidengeometrie und Effizienz voll-rotierender Feilen. Endodontie $2003 ; 12: 229-241$.

Sunday D. Cutting edge geometry and efficiency of fully rotating nickel-titanium files. Endodontics.2003;12:229-241. (In Germ.). 